\section{Notaike}

Vol. 3 No. 1, Februari 2020
e-ISSN: 2655-9404

p-ISSN: $2721-8376$

DOI: $10.20473 /$ ntr.v3i1.19023

Article history: Submitted 5 January 2020 ; Accepted 15 January 2020; Available online 1 February 2020.

\title{
Perjanjian Pengusahaan Tanah Perkebunan Yang Dikuasai Badan Hukum Oleh Pihak Ketiga
}

\author{
Iqra Elma Nurtama \\ Iqra.elma.nurtama-2016@fh.unair.ac.id \\ Universitas Airlangga
}

\begin{abstract}
One of the obligations of plantation companies mentioned in Article 58 of UU Perkebunan states that plantation companies that have Plantation Business Permits and Cultivation Business Permits are required to provide plantation facilities of around $20 \%$ of the total area being cultivated, for later plantation facilities can be done in partnership with a production sharing system or other forms of agreement, the construction of community plantation facilities should be regulated further in a Government Regulation but until now the Government Regulation has not yet been issued, so that several regulations relating to the total area of community plantation facilities overlap. Plantation companies in the business of plantation land are regulated in Article 16 of the UU Perkebunan which states that plantation businesses must cultivate at least $30 \%$ of the plantation area in no later than 3 years after granting land rights and no later than 6 years after granting compulsory land rights to cultivate the entire area of plantation land that can be planted with estate crops, then by paying attention to the principle of social function and article 15 of the UUPA it should be that plantation land above the Right to Cultivate can be promised with a third party, but it is mentioned in Article 12 PP No. 40 of 1996 that one of the obligations of the holder of a land use rights is to cultivate the land of the land for business use in accordance with the feasibility of the business. Based on this research shows that, the Agreement on the exploitation of plantation land on the land of the Cultivation Rights which is controlled by a legal entity by a third party is permitted so that it does not result in the Land of Cultivation Rights returning to the land which is controlled by the state.
\end{abstract}

Keywords: Cultivation Rights; Community Plantation Facilities; Land Exploitation Agreement.

\begin{tabular}{l} 
Abstrak \\
\hline Salah satu kewajiban perusahaan perkebunan yang disebutkan dalam Pasal 58 UU \\
Perkebunan menyatakan bahwa perusahaan perkebunan yang memiliki Izin Usaha \\
Perkebunan serta Izin Usaha Budidaya wajib menyediakan fasilitas perkebunan sekitar \\
$20 \%$ dari total luas areal yang diusahakan, untuk kemudian fasilitas perkebunan dapat \\
dilakukan dengan sistem kemitraan dengan sistem bagi hasil ataupun bentuk perjanjian \\
lain, pembangunan fasilitas perkebunan masyarakat seharusnya diatur lebih lanjut dalam \\
Peraturan Pemerintah namun hingga saat ini Peraturan Pemerintah belum diterbitkan, \\
sehingga beberapa peraturan terkait total luas fasilitas perkebunan rakyat tumpang tindih. \\
Perusahaan perkebunan dalam mengusahakan tanah perkebunan diatur dalam Pasal 16 \\
UU Perkebunan yang menyatakan bahwa pelaku usaha perkebunan wajib mengusahakan \\
paling sedikit 30\% dari luas tanah perkebunan dalam waktu paling lambat 3 tahun setelah \\
pemberian hak atas tanah dan paling lambat 6 tahun setelah pemberian hak atas tanah \\
wajib untuk diusahakan seluruh luas tanah perkebunan yang dapat ditanami tanaman \\
perkebunan, maka dengan memperhatikan asas fungsi sosial dan pasal 15 UUPA \\
seharusnya tanah perkebunan diatas Hak Guna Usaha dapat diperjanjikan dengan pihak \\
ketiga, namun disebutkan dalam Pasal 12 PP No. 40 Tahun 1996 menyatakan bahwa \\
salah satu kewajiban pemegang Hak Guna Usaha adalah mengusahakan tanah Hak Guna
\end{tabular}


Usaha sendiri sesuai dengan kelayakan usaha. Berdasarkan penelitian ini menunjukkan bahwa, Perjanjian pengusahaan tanah perkebunan diatas tanah Hak Guna Usaha yang dikuasai badan hukum oleh pihak ketiga diperbolehkan sehingga tidak mengakibatkan tanah Hak Guna Usaha kembali menjadi tanah yang dikuasai negara.

Kata Kunci: Hak Guna Usaha; Fasilitas Perkebunan Masyarakat; Perjanjian Pengusahaan tanah.

\section{Pendahuluan}

Copyright $@ 2020$ Universitas Airlangga

(c) (i)(3) (2)

Perusahaan perkebunan dalam menguasai dan mengusahakan tanah perkebunan dengan skala tertentu dapat dilakukan diatas tanah Hak Guna Usaha, berdasarkan Pasal 28 ayat (1) UUPA dan PP No. 40 Tahun 1996 tentang Hak Guna Usaha, Hak Guna Bangunan, dan Hak Pakai Atas Tanah, menyebutkan pengertian Hak Guna Usaha adalah hak untuk mengusahakan tanah yang dikuasai langsung oleh negara dalam jangka waktu pertama kalinya adalah paling lama 35 tahun dan dapat diperpanjang 25 tahun, guna perusahaan pertanian, perikanan, peternakan, dan perkebunan.

UU No. 39 Tahun 2014 tentang Perkebunan bertujuan untuk meningkatkan kesejahteraan rakyat, meningkatkan devisa negara, menyediakan lapangan kerja dan kesempatan usaha, meningkatkan produksi dan daya saing pasar, memberikan perlindungan kepada pelaku usaha perkebunan dan masyarakat. Dalam meningkatkan kesejahteraan masyarakat sekitar perkebunan peran Pemerintah sangat diperlukan.

Peran Pemerintah diwujudkan dengan sebagaimana yang diatur dalam Pasal 58 UU Perkebunan terkait salah satu kewajiban perusahaan perkebunan. Pasal 58 UU Perkebunan menyatakan bahwa Perusahaan perkebunan untuk budidaya wajib memfasilitasi pembangunan kebun masyarakat paling rendah seluas $20 \%$ dari total luas areal perkebunan yang diusahakan, pembangunan kebun masyarakat dapat dilakukan dengan pola a kredit, bagi hasil ataupun perjanjian lain. Peraturan lebih lanjut terkait peraturan pelaksana pembangunan fasilitas kebun masyarakat sebagaimana dalam Pasal 59 UU Perkebunan yang disebutkan bahwa peraturan pelaksana diatur lebih lanjut dalam Peraturan Pemerintah 
hingga saat ini belum diatur. ${ }^{1}$

Salah satu kewajiban pelaku usaha perkebunan sebagai pemegang Hak Guna Usaha diatur dalam Pasal 12 ayat (1) huruf c Peraturan Pemerintah No. 40 Tahun 1996 tentang Hak Guna Usaha, Hak Guna Bangunan dan Hak Pakai atas tanah menyatakan bahwa kewajiban pemegang Hak Guna Usaha adalah mengusahakan sendiri Hak Guna Usaha dengan baik sesuai kelayakan usaha.

Peraturan kewajiban mengerjakan tanah oleh pemegang Hak Guna Usaha merupakan salah satu instrument guna mewujudkan efesiensi dan memaksimalkan hasil produksi perkebunan. Peraturan mengusahakan sendiri Hak Guna Usaha diharapkan dalam memberikan hak diatas Hak Guna Usaha diberikan sesuai dengan kemampuan dan kapasistas dari pemegang hak atas tanah, sehingga dapat menghindarkan pemusatan penguasaan tanah oleh beberapa pemilik modal/perusahaan.

Pengusahaan atas tanah perkebunan diatur dalam Pasal 16 UU Perkebunan yang menyatakan bahwa pelaku usaha perkebunan wajib mengusahakan paling sedikit $30 \%$ dari luas tanah perkebunan dalam waktu paling lambat 3 tahun setelah pemberian hak atas tanah. Paling lambat 6 tahun setelah pemberian hak atas tanah wajib untuk diusahakan seluruh luas tanah perkebunan yang dapat ditanami tanaman perkebunan. Dengan memperhatikan asas fungsi sosial dan Pasal 15 UUPA, maka seharusnya tidak hanya pemegang hak atas tanah perkebunan saja yang memiliki kewajiban untuk meningkatkan kesuburan atas tanah, kewajiban meningkatkan kesuburan atas tanah juga merupakan kewajiban pihak yang memiliki hubungan hukum dengan tanah. Hubungan hukum atas tanah salah satunya dapat timbul berdasarkan perjanjian.

Perjanjian pengusahaan tanah perkebunan merupakan perjanjian yang bertujuan menguntungkan kedua belah pihak, karena perjanjian pengusahaan tanah dilakukan dengan salah satu pihak yang belum mampu mengusahakan

\footnotetext{
1 Mutiara Panjaitan, 'Faktor Penghambat Alokasi Luas Lahan Kebun Plasma Sebagai Syarat Perolehan Hak Guna Usaha Perkebunan Kelapa Sawit' (Tesis, Fakultas Hukum Universitas Sumatera Utara 2019) .' (Universitas Sumatera Utara 2019).[8-9].
} 
tanah dengan maksimal dan pihak lain memiliki lahan garap yang sempit atau tidak memiliki lahan garap.

Perjanjian memiliki dua bentuk yakni lisan dan tulisan. Setiap pihak dalam perjanjian pengusahaan tanah perkebunan memerlukan kepastian hukum atas perjanjian. Dalam perjanjian pengusahaan tanah perkebunan, perusahaan perkebunan sebagai pemegang hak atas tanah cenderung memiliki posisi dominan dalam perjanjian sehingga dalam menetapkan hak dan kewajiban perusahaan perkebunan memiliki posisi tawar menawar yang lebih menguntungkan.

Perjanjian antara penggarap tanah perkebunan dengan pelaku usaha diperlukan kesepakatan, kesepakatan ditujukan untuk mewujudkan adanya persamaan hak, batas-batas hak dan kewajiban masing-masing pihak, serta menghindarkan potensi konflik antara para pihak. Perjanjian dituangkan dalam akta tertulis sebagai upaya perlindungan hukum dan kepastian hukum atas perjanjian pengusahaan tanah perkebunan. ${ }^{2}$

\section{Rumusan Masalah}

Berdasarkan latar belakang yang telah diuraikan sebelumnya, maka yang menjadi rumusan masalah adalah:

1. Implementasi atas perjanjian pengusahaan tanah perkebunan oleh pihak ketiga

2. Akibat hukum atas perjanjian pengusahaan tanah perkebunan oleh pihak ketiga

\section{Tanah Perkebunan}

Tujuan dibentuknya UU Perkebunan adalah pertama, berdasarkan Pasal 33 UUD NRI 1945, yang mewujudkan dasar filosofis bahwa air, bumi, dan kekayaan alam yang terkandung di wilayah NRI merupakan anugerah Tuhan YME untuk dimanfaatkan, dikelola serta digunakan sebesar besarnya bagi kemakmuran rakyat Indonesia. Kedua, berdasarkan aspek sosiologis perkebunan memiliki peran

\footnotetext{
2 Amira Inaz Clarissa Pambudi, 'Prinsip Kepastian Hukm Kemitraan Petani Penggarap Dengan Perusahaan Perkebunan Atas Tanah Hak Guna Usaha' (Universitas Jember 2019).[19].
} 
penting dalam pertumbuhan ekonomi negara. Ketiga, berdasarkan aspek yuridis bahwa penyelenggaraan perkebunan berdasarkan UU No. 18 Tahun 2004 tentang Perkebunan sudah tidak sesuai dan tidak mampu mengakomodir kebutuhan masyarakat, serta mentindak lanjuti PMK No. 55/PUU-VIII/2010 dalam perkara permohonan pengujian UU No. 18 Tahun $2004 .^{3}$

Perkebunan merupakan salah satu faktor penunjang perekonomian Indonesia. Dalam Pasal 1 angka 1 UU No. 39 Tahun 2014 tentang Perkebunan yang selanjutnya disebut sebagai UU Perkebunan, disebutkan bahwa pengertian perkebunan adalah segala kegiatan yang berkaitan dengan sumber daya alam, sumber daya manusia, maupun teknologi pengolahan dan pemasaran terkait tanaman perkebunan. ${ }^{4}$

Berdasarkan Pasal 1 angka 2 UU Perkebunan, disebutkan bahwa pengertian tanaman perkebunan ialah tanaman semusim atau tanaman tahunan yang karena jenis dan pengolahannya ditetapkan sebagai tanaman perkebunan. Sedangkan berdasarkan Pasal 1 angka 4 UU Perkebunan yang dimaksud dengan tanah ialah permukaan bumi, baik yang berupa daratan maupun yang tertutup air dalam batas tertentu sepanjang penggunaan dan pemanfaatnya terkait langsung dengan bumi. Maka berdasarkan UU perkebunan yang dimaksud dengan tanah perkebunan ialah permukaan bumi berupa daratan yang digunakan untuk kegiatan berkaitan dengan sumber daya alam, sumber daya manusia, teknologi pengolahan dan pemasaran terkait tanaman perkebunan.

Pasal 1 angka 8 UU Perkebunan menyebutkan bahwa pelaku usaha perkebunan adalah pekebun dan perusahaan perkebunan. Pekebun adalah orang perseorangan warga negara Indonesia yang melakukan usaha perkebunan tidak mencapai dalam skala tertentu. Sedangkan, yang dimaksud sebagai perusahaan perkebunan ialah badan usaha yang berbadan hukum, didirikan berdasarkan hukum Indonesia dan berkedudukan di wilayah Indonesia yang mengelola usaha perkebunan dalam skala tertentu.

\footnotetext{
3 Ermanto Fahamsyah, 'UU Perkebunan Dan Urgensi Peraturan Pelaksanannya' <https:// business-law.binus.ac.id/2014/12/14/uu-perkebunan-dan-urgensi-peraturan pelaksanaannya/>.

4 Safira Aulia Nisa, 'Pengaturan Terhadap Keberadaan Tnah Terlantar Dengan Status Hak Guna Usaha Perusahaan Perkebunan Tratak’ (Universitas Jember 2019).[25].
} 
Pelaku usaha perkebunan wajib memiliki izin atas usaha perkebunan yang dilakukan karena izin merupakan instrument pemerintah dalam melakukan pengawasan atas aktifitas yang dilakukan masyarakat. ${ }^{5}$ Berdasarkan Peraturan Menteri Pertanian No. 98/Permentan/OT.140/9/2013 tentang Pedoman Perizinan Usaha Perkebunan terdapat 3 jenis izin dalam usaha perkebunan yakni Izin Usaha Perkebunan untuk budidaya, Izin Usaha Perkebunan, Izin Usaha Perkebunan untuk Pengolahan.

\section{Penguasaan Tanah Perkebunan oleh Badan Hukum}

Berdasarkan Pasal 2 UUPA negara berhak menguasai tanah, bumi, air dan ruang angkasa. Hak atas tanah dapat diberikan oleh Negara berdasarkan hak menguasai negara atas tanah. Negara memberikan hak atas tanah kepada badan hukum, artinya negara memberikan kewenangan atas tanah kepada pihak lain, oleh karena itu negara memiliki batas kewenangan dalam hak atas tanah. Kewenangan penguasaan negara atas tanah tidak hapus begitu saja terhadap tanah yang hak atas tanahnya telah diberikan kepada pihak lain. Negara berhak mengatur atas penyelenggaraan hak atas tanah, peruntukan, pengunaan, mengatur hubungan hukum serta mengatur perbuatan hukum atas tanah. ${ }^{6}$

\section{Hak Guna Usaha}

Usaha perkebunan membutuhkan lahan tanah yang luas, maka sebagian besar perusahaan perkebunan menguasai tanah perkebunan diatas tanah Hak Guna Usaha dengan syarat luas minimum Hak Guna Usaha sebagaimana yang telah diatur dalam Pasal 28 ayat (2) UUPA Jo. Pasal 5 PP No. 40 Tahun 1996 yakni luas minimum atas Hak Guna Usaha untuk badan hukum adalah 5 hektar dan luas maksimal ditetapkan oleh Kepala Badan Pertanahan Nasional. Hak Guna usaha

5 Tatiek Sri Djamiati,[et., Al], Buku Ajar Hukum Perizinan (Fakultas Hukum Universitas Airlangga 2012).[1].

6 Boedi Harsono, Hukum Agraria Indonesia Sejarah Pembentukan Undang- Undang Pokok Agraria, Isi Dan Pelaksanaannya (Djambatan 2008).[273]. 
merupakan hak atas tanah bersifat tetap yang disebutkan dalam Pasal 16 UUPA. ${ }^{7}$

Dalam Pasal 28 ayat (1) UUPA disebutkan bahwa Hak Guna Usaha ialah hak untuk mengusahakan tanah yang dikuasai langsung oleh negara, dalam jangka waktu tertentu, guna perusahaan pertanian, perikanan dan peternakan. Berdasarkan Pasal 14 ayat (1) PP 40 tahun 1996 terdapat penambahan terkait penggunaan Hak Guna Usaha untuk usaha dibidang perkebunan. ${ }^{8}$

Tanah negara yang dapat diberikan Hak Guna Usaha harus memenuhi beberapa syarat yakni, kawasan hutan yang telah dialihkan menjadi status menjadi lahan yang dapat dijadikan untuk pertanian, perkebunan, perikanan dan peternakan, tanah Hak Guna Usaha harus dikuasai langsung oleh negara, oleh karena itu apabila tanah yang menjadi obyek atas Hak Guna Usaha berada dalam penguasaan hak tertentu, hak tersebut harus dilepaskan, sehingga tanah atas hak kembali menjadi tanah yang dikuasai oleh negara untuk kemudian diberikan status Hak Guna Usaha atas tanah yang telah dilakukan pelepasan haknya, apabila diatas tanah yang akan diberikan Hak Guna Usaha terdapat bangunan atau gedung, maka pemilik bangunan tersebut harus diberikan ganti kerugian. ${ }^{9}$

\section{Subjek Hak Guna Usaha}

Subjek Hak Guna Usaha sebagaimana yang diatur diatur dalam Pasal 30 UUPA Jo. Pasal 2 PP No. 40 Tahun 1996 yakni warga negara Indonesia dan badan hukum yang didirikan menurut hukum Indonesia serta berkedudukan di Indonesia. Perusahaan perkebunan yang membutuhkan tanah perkebunan diatas tanah Hak Guna Usaha dapat mengajukan pemberian hak diatas tanah Hak Guna Usaha atas tanah.

7 Tri Purnami, Pelaksanaan Bagi Hasil Tanah Pertanian, Studi Komparatif Undang-Undang No.2 Tahun 1960 Tentang Perjanjian Bagi Hasil Tanah Pertanian Dengan Pelaksanaan Bagi Hasil Di Desa Blagungan Kecamatan Kalijambe Kabupaten Sragen (Universitas Muhammadiyah Surakarta 2012).[2].

8 Urip Santoso, Hukum Agraria Kajian Komperhensif (Kencana 2017).[101].

9 Janri Wolden Halomoan Sirait, 'Implementasi Kebijakan Pemberian Hak Guna Usaha' (2017) 14 Ilmu Administrasi Negara.[1]. 
Berdasarkan Pasal 8 PP 40 Tahun 1996 telah diatur bahwa jangka waktu Hak Guna Usaha paling lama 35 tahun dan dapat diperpanjang paling lama sampai 25 tahun, lalu dapat di perbarui lagi hingga 35 tahun, perpanjangan Hak Guna Usaha harus dilakukan 2 tahun sebelum jangka waktu Hak Guna Usaha berakhir.

\section{Kewajiban Pemegang Hak Guna Usaha Tanah Perkebunan}

Perusahaan perkebunanharus menjalankankewajibandenganditetapkannya Hak Guna Usaha untuk perusahaan perkebunan, kewajiban pemegang Hak Guna usaha yang diatur dalam Pasal 12 PP No. 40 Tahun 1996, yakni meliputi :

a. Dengan diterbitkannya Hak Guna Usaha maka pemegang Hak Guna Usaha wajib Membayar Uang atas / pemasukan;

b. Menjalankan usaha perkebunan, perternakan, dan pertanian sesuai dengan syarat yang telah ditetapkan atas pemberian haknya;

c. Mengusahakan sendiri tanah Hak Guna Usaha, sesuai dengan syarat yang telah ditetapkan oleh instansi yang ditetapkan;

d. Membangun, Menjaga, fasilitas tanah dan prasana lingkungan di wilayah Hak Guna Usaha;

e. Memelihara dan meningkatkan kesuburan tanah serta mencegah kerusakan lingkungan yang dimungkinkan menimbulkan akibat usaha perkebunan;

f. Setiap akhir tahun menyampaikan laporan tertulis;

g. Apabila Hak Guna Usaha hapus maka pemegang Hak Guna Usaha harus menyerahkan kembali tanah Hak Guna Usaha kepada negara;

h. Menyerahkan Sertifikat Hak guna Usaha kepada Kepala Kantor Pertanahan.

Selain kewajiban sebagaimana disebutkan dalam Pasal 12 PP No. 40 tahun

1996, pemegang Hak Guna Usaha atas tanah perkebunan yang memiliki IUP dan IUPB, memiliki kewajiban yang diatur dalam UU Perkebunan yang diantaranya ialah kewajiban atas pembangunan fasilitas kebun masyarakat.

\section{Kewajiban atas Pembangunan Fasilitas Kebun Masyarakat}

Pengalihan penguasaan tanah yang dikuasai masyarakat kepada negara, kemudian tanah dikuasai oleh perusahaan perkebunan diatas tanah Hak Guna Usaha menimbulkan terjadinya perubahan pola pekerjaan masyarakat perkebunan. Selain itu dengan penguasaan tanah perkebunan oleh perusahaan perkebunan menimbulkan ketimpangan kesejahteraan antara pekebun dengan perusahaan perkebunan karena dalam hal ini perkebunan 
yang di kuasai dan diusahakan perusahaan perkebunan relatif maju karena menguasai aset produksi (lahan, modal, tenaga kerja, sarana produksi dan teknologi) dan pasar secara penuh, sedangkan perkebunan yang diusahakan oleh masyarakat secara individu relatif tertinggal karena asset yang dikuasai terbatas. ${ }^{10}$

Upaya pemerintah untuk melindungi hak masyarakat atas pekerjaan serta meningkatkan kemakmuran masyarakat sekitar perkebunan diwujudkan dengan adanya kebijakan pola kerjasama antara perusahaan perkebunan dengan masyarakat. Hal tersebut diatur dalam Pasal 58 UU Perkebunan tentang salah satu kewajiban perusahaan perkebunan yang menyatakan bahwa adanya kewajiban menyediakan fasilitas kebun masyarakat dengan luas minimal 20\% (dua puluh persen) dari total luas areal kebun yang diusahakan oleh perusahaan perkebunan, yang memiliki izin usaha perkebunan atau izin usaha perkebunan untuk budidaya, pembangunan kebun masyarakat dapat dilakukan melalui melalui pola kredit, perjanjian bagi hasil, maupun bentuk pendanaan lain.

Perusahaan perkebunan diharapkan tidak hanya menguntungkan pihak penanam modal, namun juga dapat menguntungkan masyarakat sekitar perkebunan, dengan adanya perusahaan perkebunan diharapkan perusahaan perkebunan mampu memberdayakan masyarakat sekitar perkebunan.

Pasal 59 UU Perkebunan menyebutkan bahwa pembangunan fasilitas kebun masyarakat akan diatur lebih lanjut dalam Peraturan Pemerintah. Namun hingga saat ini Peraturan Pemerintah yang berfungsi sebagai peraturan pelaksana teknis pembangunan fasilitas perkebunan masyarakat belum diterbitkan, sehingga peraturan teknis terkait pembangunan fasilitas masyarakat masih tumpang tindih beberapa peraturan.

10 Undang Fadjar, Kemitraan Usaha Perkebunan: Perubahan Struktur Yang Belum Lengkap (Forum Penelitian Agro Ekonomi 2006).[47]. 
Tabel 1: Perbedaan peraturan luas pembangunan fasilitas perkebunan rakyat

\begin{tabular}{|c|c|c|}
\hline $\begin{array}{c}\text { UU Perkebunan } \\
\text { (Pasal 58) }\end{array}$ & $\begin{array}{c}\text { Peraturan Menteri } \\
\text { Pertanian No. 98/ } \\
\text { Permentan/OT.140/9/2013 } \\
\text { (Pasal 15) }\end{array}$ & $\begin{array}{c}\text { Peraturan Menteri Agraria } \\
\text { No. } 7 \text { tahun } 2017 \text { tentang } \\
\text { Pengaturan dan tata cara } \\
\text { penetapan Hak Guna } \\
\text { Usaha } \\
\text { (Pasal } 40 \text { huruf k dan Pasal } \\
\text { 41) } \\
\end{array}$ \\
\hline $\begin{array}{l}\text { Perusahaan perkebunan } \\
\text { yang memiliki izin } \\
\text { usaha perkebunan atau } \\
\text { izin usaha perkebunan } \\
\text { untuk budidaya wajib } \\
\text { menyediakan fasilitas } \\
\text { kebun masyarakat dengan } \\
\text { luas minimal 20\% (dua } \\
\text { puluh persen) dari total } \\
\text { luas areal kebun yang } \\
\text { diusahakan (Sesuai dengan } \\
\text { Izin UsahaPerkebunanatau } \\
\text { Izin Usaha Perkebunan } \\
\text { Untuk Budidaya }\end{array}$ & $\begin{array}{l}\text { Perusahaan perkebunan } \\
\text { dengan luas } 250 \text { hektar atau } \\
\text { lebih yang mengajukan } \\
\text { IUP-B atau IUP wajib untuk } \\
\text { membangun fasilitas kebun } \\
\text { masyarakat dengan luas } \\
20 \% \text { dari luas IUP atau } \\
\text { IUPB. Kebun masyarakat } \\
\text { yang difasilitasi, } \\
\text { pembangunannya berada di } \\
\text { luar areal IUP-B atau IUP. }\end{array}$ & $\begin{array}{l}\text { Pemohon Hak Guna Usaha } \\
\text { pertama kali dengan luas } \\
250 \text { Ha atau lebih wajib } \\
\text { memfasilitasi kebun } \\
\text { masyarakat minimal } \\
20 \% \text { dari luas tanah yang } \\
\text { dimohon Hak Guna Usaha } \\
\text { untuk kemitraan dalam } \\
\text { bentuk plasma. }\end{array}$ \\
\hline
\end{tabular}

Menurut Direktur Jendral Perkebunan Kementrian Pertanian RI dalam Majalah infosawit dengan judul “DirjenBun : 20\% Kewajiban Lahan Plasma Sawit Di Luar HGU" menyatakan bahwa porsi atas fasilitas pembangunan perkebunan rakyat adalah 20\% diluar Hak Guna Usaha yang sudah dimiliki, yang artinya pengusaha harus menambah 20\% kepemilikan atas lahan untuk pembangunan fasilitas perkebunan rakyat. ${ }^{11}$

Peraturan Menteri Agraria No. 7 tahun 2017 tentang Pengaturan dan tata cara penetapan Hak Guna Usaha belaku Lex Posteriori Derograt Legi Priori atas Peraturan Menteri Pertanian No. 98 Tahun 2013. Selain itu keberlakuan atas Peraturan Menteri agararia dipertegas dengan adanya Instruksi Presiden Nomor 8 tahun 2018 Tentang Penundaan dan Evaluasi Perizinan Perkebunan Kelapa Sawit Serta Peningkatan Produktivitas Perkebuanan Kelapa Sawit.

Inspres Nomor 8 tahun 2018 menyatakan bahwa pelaksaan fasilitas perkebunan masyarakat dilakukan dengan luas 20\% dari Hak Guna Usaha yang dalam hal penerbitan hak atas tanah untuk fasilitas perkebunan masyarakat dilakukan oleh Menteri Agraria dan Tata Ruang, maka peraturan yang diterapkan

${ }^{11}$ Panjaitan (n 1).,Op,Cit. [15]. 
terkait fasilitas perkebunan masyarakat adalah Peraturan Menteri Agraria No. 7 tahun 2017 tentang Pengaturan dan tata cara penetapan Hak Guna Usaha yang menyatakan bahwa perusahaan perkebunan yang yang memohonkan Hak Guna Usaha dengan luas 250 Ha untuk pertama kali wajib memfasilitasi kebun masyarakat minimal 20\% dari luas tanah yang dimohon Hak Guna Usaha untuk masyarakat sekitar dalam bentuk kemitraan (Plasma).

Inpres merupakan "policy rules" yaitu bentuk peraturan kebijakan yang tidak dapat dikategorikan sebagai peraturan perundang undangan yang biasa. Keberlakuan berdasarkan Inpres tidak dapat berlaku umum, Inpres berlaku individual atau beschikking, selain itu dalam Instruksi Presiden Nomor 8 tahun 2018 hanya terkait perkebunan kelapa sawit, oleh karena itu dalam hal keberlakuan atas peraturan fasilitas perkebunan masyarakat yang seharusnya berlaku untuk semua usaha bidang perkebunan diperlukan Peraturan Pemerintah sebagai peraturan pelaksana sehingga dengan adanya Peraturan Pemerintah tersebut memberikan kepastian hukum yang mengikat seluruh pihak dalam usaha perkebunan.

\section{Perusahaan Inti Rakyat}

Pasal 40 dan 41 Peraturan Menteri Agraria No.7 Tahun 2017 terkait pembangunan fasilitas kebun masyarakat, menyatakan bahwa fasilitas kebun masyarakat untuk masyarakat sekitar perkebunan dalam bentuk kemitraan (plasma), permohonan hak atas tanah bagian kemitraan plasma untuk masyarakat peserta plasma perorangan permohonan hak atas tanah yang diajukan dalam bentuk hak milik dan untuk masyarakat plasma yang tergabung dalam badan hukum permohonannya dalam bentuk Hak Guna Usaha. Permohonan Hak Guna Usaha kemitraan diajukan bersamaan dengan permohonan Hak Guna Usaha inti.

Hubungan inti plasma adalah suatu model hubungan kerjasama yang diharapkan dapat terjadi seperti harmonisnya inti dan plasma dalam sebuah sel. PIR merupakan pola pelaksanaan pengembangan perkebunan dengan mengunakan perkebunan besar sebagai inti yang membantu perkebunan rakyat disekitarnya sebagai plasma. 
Dalam perjanjian PIR, tanah diberikan kepada petani dengan Hak milik namun sebelum pemberian Hak milik, PIR dilalui melalui beberapa tahap yakni:12

1. Tahap persiapan yang meliputi persiapan proyek;

2. Tahap pembangunan fisik baik kebun maupun pemukiman, serta berbagai prasarana, dalam tahap ini juga dilakukan persiapan petani sebagai nasabah langsung dari bank, yang mana dalam tahap ini bank sudah mengeluarkan kredit kepada pelaksana proyek;

3. Konversi, yaitu tahap pengalihan pemilikan kebun plasma dan beban kredit kepada petani peserta, kredit yang semula disalurkan kepada pelaksana proyek dialihkan kepada petani peserta;

4. Pasca konversi, yaitu tahap pengembangan yang meliputi masa pelunasan kredit, pembinaan tani dan usaha tani menuju terbentuknya petani mandiri.

Skema 1

Mekanisme Perjanjian PIR

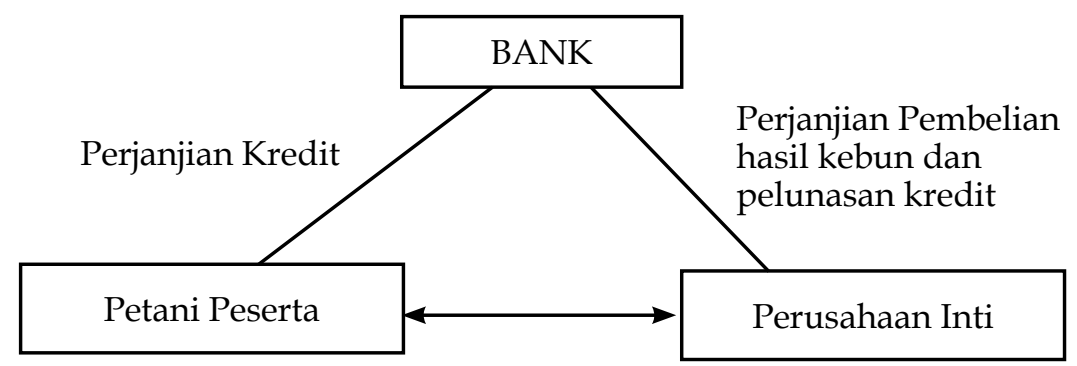

Perjanjian Produksi dan jual beli hasil kebun petani peserta

Sumber: Ermanto Fahamsyah, Hukum Perkebunan (LaksBang PRESSindo 2018).[62].

Perjanjian kredit yang dilakukan petani peserta PIR ditujukan untuk biaya pembangunan kebun, rumah, pembukaan tanah pekarangan, jalan kebun dan sertifikat tanah.

Peraturan Menteri Agraria No.7 Tahun 2017 menyatakan bahwa kewajiban pembangunan fasilitas kebun masyarakat ditujukan bagi pihak pemohon Hak Guna Usaha pertama kali dengan luas minimal $250 \mathrm{Ha}$.

Berdasarkan sisi ekonomi pemberian Hak Guna Usaha merupakan harapan atas terjadinya kemakmuran dan peningkatan perekonomian baik bagi negara, pelaku usaha maupun masyarakat luar perkebunan. Negara memiliki hak menguasai negara atas tanah, oleh karena itu, pemerintah memiliki kedudukan

\footnotetext{
${ }^{12}$ Ermanto Fahamsyah, 'Hukum Perkebunan (Jenis Dan Bentuk Perjanjian Dalam Pola Perusahaan Inti Rakyat Perkebunan Kelapa Sawit' [2018] Justitia.[40].
} 
sebagai pemberi hak dan perusahaan perkebunan sebagai penerima hak, maka dengan hal tersebut menimbulkan hubungan hukum (keperdataan) antara pemberi hak dan penerima hak atas tanah yang akan menimbulkan kewajiban. ${ }^{13}$

Tanah perkebunan yang dikuasai dengan skala tertentu dapat dilakukan diatas Hak Guna Usaha. Kewajiban atas penguasaan tanah diatas Hak Guna Usaha diatur dalam Pasal 12 PP No. 40 tahun 1996 yang disebutkan bahwa kewajiban pemegang Hak Guna Usaha salah satunya ialah mengusahakan sendiri tanah Hak Guna Usaha dengan baik sesuai dengan kelayakan usaha berdasarkan kriteria yang ditetapkan oleh instansi teknis dan memelihara kesuburan tanah, mencegah kerusakan sumber daya alam, dan menjaga kelestarian kemampuan lingkungan hidup.

Kriteria yang ditetapkan intansi teknis terkait kelayakan pengusahaan tanah perkebunan yang dikuasai perusahaan perkebunan diatur dalam Pasal 16 UU Perkebunan yang menyebutkan bahwa perusahaan perkebunan wajib mengusahakan tanah perkebunan paling sedikit $30 \%$ dari luas hak atas tanah paling lambat 3 tahun sejak pemberian hak atas tanah. Paling lambat 6 tahun sejak pemberian hak perusahaan perkebunan wajib mengusahakan seluruh luas tanah perkebunan yang dapat ditanami. Latar belakang peraturan tersebut atas dasar kesiapan perusahaan perkebunan dalam penglolaan tanah perkebuanan, karena pada awal penguasaan Hak Guna Usaha tanah perkebunan, pihak perusahaan belum memiliki kemampuan pengelolaan lahan dan kesiapan sumber daya manusia untuk mengelola lahan, oleh karena itu perusahaan perkebunan diberikan waktu untuk kesiapan atas pengelolaan lahan.

Setiap penguasa hak atas tanah wajib memperhatikan asas fungsi sosial, karena dalam Pasal 6 UUPA disebutkan bahwa setiap hak atas tanah mempunyai asas fungsi sosial, yang mana berdasarkan fungsi sosial maka sudah sewajarnya bahwa hak atas tanah dipelihara dengan baik dan ditingkatkan kesuburannya, ${ }^{14}$

13 Suharningsih, 'Kebijakan Pertanahan Pada Era Otonomi Daerah Di Bidang Hak Guna Usaha Perkebunan' (2011) 23 Mimbar Hukum.[268].

${ }^{14}$ Urip Santoso (n 8)., Op,Cit. [352]. 
96 Iqra Elma: Perjanjian Pengusahaan Tanah...

dalam pasal 15 UUPA disebutkan bahwa kewajiban untuk memelihara dan meningkatkan kesuburan tanah bukan hanya kewajiban bagi pemegang hak, namun juga bagi setiap orang atau badan hukum yang memiliki hubungan hukum dengan tanah tersebut. Hubungan hukum atas tanah dapat terjadi melalui beberapa hal seperti adanya perjanjian pengusahaan tanah.

\section{Perjanjian Pengusahaan Tanah Perkebunan Yang Dikuasai Badan Hukum.}

Perjanjian pengusahaan tanah perkebunan milik perusahaan oleh pihak ketiga menimbulkan hak atas tanah bersifat sementara. Hak atas tanah bersifat sementara adalah hak yang memberikan kewenangan kepada pihak lain untuk mengusahakan tanah, sebagaimana diatur dalam Pasal 53 UUPA. ${ }^{15}$

Beberapa jenis perjanjian pengusahaan tanah perkebunan diantaranya adalah:

\section{a. Sewa Menyewa}

Pengertian sewa menyewa dalam BW disebutkan dalam Pasal 1548 BW, yang disebutkan bahwa perjanjian sewa menyewa adalah suatu perjanjian antara para pihak yang mengikatkan dirinya untuk memberikan kenikmatan kepada pihak lainnya dari suatu barang, dalam jangka waktu tertentu yang diikuti dengan pembayaran sesuai dengan kesepakatan para pihak dalam perjanjian. Perjanjian sewa menyewa merupakan perjanjian konsensuil, oleh karena itu perjanjian sewa menyewa berlaku mengikat saat tercapainya kesepakatan mengenai objek sewa dan harga sewa antara para pihak. ${ }^{16}$

Perjanjian sewa menyewa tanah perkebunan merupakan salah satu bentuk hak atas tanah yang bersifat sementara yang diatur dalam Pasal 53 UUPA, Perjanjian sewa tanah perkebunan adalah perjanjian antara pihak petani penggarap tanah perkebunan dengan perusahaan perkebunan yang berkedudukan sebagai penguasa tanah perkebunan diatas Hak Guna Usaha, yang mana perusahaan

${ }^{15}$ Tri Purnami (n 7)., Op, Cit. [2].

${ }^{16}$ Audi Yuliani Mahdi, 'Analisis Yuridis Mengenai Sengketa Kedudukan Penyewa Tanah (Studi Terhadap Putusan Pengadilan Negeri Medan No. 562/PDT.G/1995/PN-MDN)’ (Jurnal Universitas Sumatera Utara, 2019). 
perkebunan sebagai penguasa tanah menyanggupi menyerahkan penguasaan tanah perkebunan secara fisik selama waktu tertentu sedangkan pihak lain yakni petani penggarap menyanggupi membayar harga yang telah ditetapkan dalam penguasan tanah perkebunan. Pihak penyewa tanah perkebunan memiliki dua kewajiban dalam perjanjian sewa yakni membayar uang sewa pada waktu yang telah ditetapkan dan memelihara tanah perkebunan sebaik baiknya. ${ }^{17}$

\section{b. Perjanjian Bagi Hasil}

Berdasarkan UU No. 2 Tahun 1960 Pasal 1 huruf c pengertian perjanjian bagi hasil adalah perjanjian yang dilakukan oleh satu pihak sebagai penggarap dengan pihak lain baik orang perseorangan ataupun badan hukum pemilik tanah, dimana penggarap diperkenankan mengusahakan tanah pemilik dengan pembagian hasil antara kedua belah pihak. Dalam Pasal 3 UU No. 2 Tahun 1960 ditentukan bahwa semua perjanjian bagi hasil harus dibuat dihadapan pemilik dan penggarap sendiri dengan tertulis, dalam pembentukan perjanjiannya melibatkan kepala desa dan juga dua orang saksi dari masing masing pihak. ${ }^{18}$

Objek perjanjian bagi hasil bukan tanah melainkan tenaga dan tanaman. Akibat atas adanya perjanjian adalah timbulnya hak dan kewajiban para pihak dalam perjanjian. Penggarap selama perjanjian berlangsung berhak mengusahakan tanah perkebunan dan menerima bagian atas hasil pengusahaan tanah dengan seimbang, untuk mengusahakan tanah perkebunan dalam perjanjian bagi hasil penggarap wajib mengusahakan tanah dengan baik, menyerahkan bagi hasil sesuai kesepakatan para pihak, serta memenuhi beban beban yang menjadi tanggungan penggarap.

\section{Bentuk Perjanjian Pengusahaan Tanah Perkebunan}

Perjanjian merupakan sumber perikatan, menurut Subekti perikatan adalah hubungan hukum antara dua orang atau lebih, dimana salah satu pihak berhak menuntut atas sesuatu dari pihak lain, dalam hal ini pihak lain yang terikat dalam

17 ibid.[2].

18 Rizki Hidayat, 'Tinjauan Hukum Terhadap Pelaksanaan Perjanjian Bagi Hasil Usaha Tambang Emas Antara Penambang Dengan Pemilik Tanah (Studi Kasus Di Kecamatan Natal Kabupaten Mandailing Natal)' (Universitas Sumatera Utara 2017).[22]. 
perjanjian berkewajiban memenuhi tuntutan tersebut. ${ }^{19}$

Perjanjian merupakan sebuah perbuatan hukum yang akan menimbulkan akibat hukum. Perjanjian dianggap sah apabila telah memenuhi sebagaimana yang telah diatur dalam Pasal 1320 BW, yakni:

1. Kesepakatan para pihak yang mengikatkan dirinya;

2. Kecakapan para pihak;

3. Suatu pokok tertentu;

4. Suatu sebab yang diperbolehkan.

Bentuk Perjanjian terdapat dua macam yakni perjanjian tertulis dan perjanjian dalam bentuk lisan. Dalam bentuk perjanjian tertulis terbagi menjadi dua macam perjanjian tertulis sebagaimana diatur dalam Pasal 1867 BW, yakni perjanjian bawah tangan dan perjanjian diatas akta otentik. Pengertian Akta otentik diatur dalam Pasal 1868 BW adalah perjanjian yang dituangkan dalam bentuk tertulis, sebagaimana dalam bentuk yang telah ditentukan oleh undang-undang, akta dibuat oleh dan atau dihadapan pegawai umum pembuat akta.

Pejabat umum adalah notaris, hakim, juru sita, dan sebagainya. Kewenangan notaris untuk membuat akta otentik diatur dalam UU No. 30 Tahun 2004 tentang Jabatan Notaris, yang disebutkan bahwa notaris merupakan pejabat umum yang berwenang membuat akta otentik, yang dalam Pasal 15 ayat (1) UU Jabatan Notaris disebutkan bahwa notaris dalam jabatannya berwenang membuat akta otentik mengenai semua perbuatan, perjanjian, dan penetapan yang diharuskan oleh peraturan perundang undangan dan atau dikehendaki oleh para pihak dalam perjanjian. ${ }^{20}$ Dalam Pasal 15 ayat (2) huruf e UU Jabatan Notaris menyebutkan bahwa notaris berkewajiban untuk bertindak jujur, seksama, mandiri dan tidak berpihak dan menjaga kepentingan para pihak dalam perbuatan hukum.

Akta otentik merupakan alat bukti yang sempurna karena dengan kedudukan akta otentik sebagai alat bukti yang sempurna maka tidak memerlukan alat bukti 2006).[219].

19 Titik Triwulan Tutik, Pengantar Hukum Perdata Di Indonesia (Prestasi Pustaka Publisher

20 Irma Devita Purnamasari, 'Akta Notaris Sebagai Akta Otentik' (HukumOnline.com, 2015) <https://www.hukumonline.com/klinik/detail/ulasan/lt550c0a7450a04/akta-notaris-sebagai-akta-otentik/>. 
lain, apabila terdapat pihak yang meragukan keabsahan akta otentik maka orang yang mendalilkan harus membuktikan. Sedangkan akta bawah tangan adalah akta yang dibuat oleh pejabat yang tidak berwenang atau dibuat oleh para pihak dalam perjanjian.

Perjanjian sebaiknya tertulis, namun pada dasarnya tidak harus secara tertulis, kecuali diharuskan oleh undang-undang. Bentuk perjanjian pengusahaan tanah Perkebunan diatur dalam Pasal 3 UU No. 2 Tahun 1960 tentang Perjanjian Bagi Hasil yang menyatakan bahwa bahwa semua perjanjian bagi hasil harus dibuat oleh pemilik dan penggarap sendiri secara tertulis dihadapan kepala desa atau yang setingkat dengan itu, yang disertai juga dua orang saksi dalam dari masing masing pihak dalam perjanjian.

Bentuk perjanjian pengusahaan tanah perkebunan harus dituangkan dalam bentuk tertulis, namun tidak diharuskan dalam bentuk akta otentik. Dalam hal ini Perjanjian pengusahaan tanah perkebunan sebaiknya dituangkan dalam akta otentik karena akta otentik merupakan alat bukti yang sempurna, selain itu dalam pembuatan akta otentik melibatkan notaris sebagai perjabat umum yang berwenang dalam membuat akta otentik, dengan adanya notaris akan menimbulkan pengawasan dari pihak ketiga agar perjanjian sesuai hukum dan kesepakatan para pihak. pengawasan notaris diperlukan karena salah satu pihak dalam perjanjian pengusahaan tanah yakni, pihak ketiga selaku penggarap tanah perkebunan yang dikuasai badan hukum memiliki posisi tawar menawar yang lebih lemah dibandingkan dengan perusahaan perkebunan. ${ }^{21}$

\section{Eksistensi atas Tanah Perkebunan yang Dikuasai oleh Badan Hukum yang Diusahakan Pihak Ketiga}

Berdasarkan Pasal 34 UUPA Hak Guna Usaha dapat hapus dikarenakan jangka waktu berakhir, dihentikan sebelum jangka waktu berakhir karena

\footnotetext{
${ }^{21}$ Rudianto Salmon Sinaga, 'Masalah Hukum Dalam Perjanjian Kemitraan Inti Plasma Perkebunan Kelapa Sawit (Studi Kasus Pada PT.SHM Dengan Koperasi PGH) Dan Tindakan Notaris Dalam Menghadapi Perjanjian Kemitraan Inti Plasma Dalam Perkebunan Kelapa Sawit' (Tesis, Fakultas Hukum Univers' (Universitas Indonesia 2011).[15].
} 
sesuatu syarat yang tidak dipenuhi, dilepaskan oleh pemegang haknya sebelum jangka waktu berakhir, dicabut untuk kepentingan umum, ditelantarkan, tanah musnah dan orang atau badan hukum yang tidak lagi memenuhi syarat sebagai subyek Hak Guna Usaha. ${ }^{22}$ Selain sebagaimana disebutkan dalam Pasal 34 UUPA disebutkan pula dalam Pasal 17 PP No. 40 tahun 1996 terkait beberapa faktor yang mengakibatkan Hak Guna Usaha hapus dan kembali menjadi tanah milik negara, salah satu faktor yang menyebabkan Hak Guna Usaha hapus adalah tidak dipenuhinya kewajiban atau dilanggarnya ketentuan yang diatur dalam Pasal 12, 13, 14 UUPA dan putusan pengadilan. Salah satu kewajiban pemegang Hak Guna Usaha sebagaimana yang disebutkan dalam Pasal 12 PP No. 40 Tahun 1996 adalah mengerjakan sendiri Hak Guna Usaha sesuai dengan kelayakan usaha berdasarkan kriteria yang ditetapkan instansi teknis.

Mengusahakan tanah sendiri sesuai dengan kelayakan usaha adalah pertama setiap perusahaan perkebunan yang akan mengajukan permohonan Hak Guna Usaha terlebih dahulu harus memiliki kemampuan finansial yang telah sesuai dengan rencana kegiatan usaha yang telah ditetapkan/proposal, Kedua Perusahaan perkebunan yang menguasai tanah diatas Hak Guna Usaha harus mengerjakan dan mengusahakan sendiri sesuai dengan kelayakan usaha berdasarkan kriteria yang ditetapkan oleh instansi teknis. Dalam Pasal 16 UU Perkebunan dinyatakan bahwa pemegang Hak Guna Usaha dalam 3 tahun wajib mengusahakan paling sedikit 30\% dari Hak Guna Usaha sejak diberikannya hak dan dalam waktu 6 tahun sejak diberikannya hak tanah Hak Guna Usaha wajib diusahakan seluruh luas hak atas tanah yang secara teknis dapat ditanami. Ketiga apabila perusahaan perkebunan tidak mampu mengusahakan tanah sendiri, maka dapat dilakukan perjanjian pengusahaan tanah dengan pihak lain, dengan ketentuan dalam melakukan perjanjian tidak diperkenankan mengandung cara dan unsur pemerasan. ${ }^{23}$

${ }^{22}$ Urip Santoso, Pendaftaran Dan Peralihan Hak Atas Tanah (Kencana 2011).,Op, Cit.[107].

${ }^{23}$ Dyah Suhitarasmi, 'Kewajiban Pemegang Hak Guna Usaha Dalam Pemanfaatan Dan Penggunaan Tanah Di Jawa Tengah' (Tesis, Magister Kenotariatan Universitas Diponegoro 2003).' (Universitas Diponegoro 2003).[68-69]. 
Pengusahaan tanah perkebunan dapat diperjanjikan dengan pihak ketiga karena memperhatikan asas fungsi sosial dalam Pasal 6 UUPA menyatakan bahwa semua hak atas tanah memiliki fungsi sosial, yang mana dalam penjelasan UUPA diuraikan bahwa hak atas tanah memiliki fungsi sosial berarti hak atas tanah apapun yang ada pada seseorang (termasuk badan hukum) tidak dapat dibenarkan, bahwa tanahnya itu akan digunakan (atau tidak digunakan) semata mata untuk kepentingan pribadinya, apalagi kalau hal itu menimbulkan kerugian bagi masyarakat. Penggunaan tanah harus digunakan harus digunakan sesuai dengan sifat dan keadaan atas haknya, berdasarkan fungsi sosial atas tanah tersebut maka tanah harus diperlihara denngan baik, ditingkatkan kesuburannya, serta mencegah timbulnya kerusakan atas tanah. dalam Pasal 15 UUPA juga dinyatakan bahwa kewajiban atas memelihara tanah ini dibebankan kepada badan hukum maupun perseorangan yang memiliki hubungan hukum dengan tanah. ${ }^{24}$

Perjanjian pengusahaan tanah perkebunan dilakukan dengan tujuan saling menguntungkan dimana petani sekitar perkebunan yang memiliki lahan garap sempit ataupun tidak memiliki lahan garap dapat mengusahakan tanah perkebunan yang belum diusahakan dengan maksimal oleh pihak perkebunan.

Pasal 17 ayat (1) huruf b angka 1 PP No. 40 tahun 1996 menyatakan bahwa Hak Guna Usaha dibatalkan haknya oleh perjabat yang berwenang sebelum jangka waktu berakhirnya Hak Guna Usaha karena tidak dipenuhinya kewajiban oleh pemegang hak guna usaha.

Berdasarkan hak atas tanah yang memiliki asas fungsi sosial dan sebagaimana disebutkan dalam Pasal 15 UUPA pengusahaan tanah perkebunan dengan pihak ketiga dapat dilakukan sebagai salah satu upaya optimalisasi atas pengusahaan tanah perkebunan yang dalam hal ini belum mampu diusahakan oleh pihak perusahaan secara maksimal, sedangkan disisi lain petani sekitar perkebunan tidak memiliki lahan garap atau memiliki lahan garap yang sempit.

${ }^{24}$ Urip Santoso (n 8)., Op, Cit. [352]. 
Dengan dilakukannya perjanjian pengusahaan tanah perkebunan dengan pihak ketiga, perusahaan perkebunan tidak dapat dinyatakan lalai atas kewajiban pengusahaan tanah perkebunan, karena dengan diperjanjikannya tanah perkebunan dengan pihak ketiga merupakan salah satu upaya untuk meningkatkan dan menjaga kesuburan atas tanah ketika perusahaan perkebunan belum mampu mengusahakan secara maksimal dikarenakan faktor kurangnya sumber daya manusia dan kesiapan atas pengelolaan tanah perkebunan. Perjanjian pengusahaan tanah perkebunan dengan pihak ketiga tidak menghapuskan Hak Guna Usaha yang dikuasai oleh perusahaan perkebunan dan tidak mengakibatkan tanah kembali dikuasai negara.

\section{Kesimpulan}

Kewajiban perusahaan perkebunan atas Fasilitas perkebunan masyarakat dilaksanakan berdasarkan Peraturan Menteri No. 7 tahun 2017 tentang Pengaturan dan tata cara penetapan Hak Guna Usaha yang mana perusahaan perkebunan pemegang HGU yang berbadan hukum wajib memfasilitasi kebun masyarakat minimal 20\% dari luas tanah yang dimohon Hak Guna Usaha untuk kemitraan. Perjanjian kerjasama antara perusahaan perkebunan dengan pihak ketiga dalam pengusahaan tanah perkebunan yang dikuasai badan hukum dapat dilakukan melalui beberapa jenis perjanjian yakni, sewa menyewa tanah dan Bagi hasil. Dalam perjanjian pengusahaan tanah perkebunan harus dibuat secara tertulis.

Dengan adanya perjanjian pengusahaan tanah perkebunan yang dikuasai badan hukum oleh pihak ketiga tidak menghapuskan hak atas tanah yang dimiliki oleh badan hukum karena berdasarkan asas fungsi sosial dan Pasal 15 UUPA.

\section{Daftar Bacaan}

\section{Buku}

Djamiati, Tatiek Sri et al., Buku Ajar Hukum Perizinan (Fakultas Hukum, Universitas Airlangga 2012).

Fahamsyah, Ermanto, Hukum perkebunan (Jenis dan Bentuk Perjanjian Dalam Pola 
Perusahaan Inti Rakyat Perkebunan Kelapa Sawit) (LaksBang Justitia, Yogyakarta 2018).

Harsono, Boedi, Hukum Agraria Indonesia Sejarah Pembentukan Undang- undang Pokok Agraria, Isi dan Pelaksanaannya (Djambatan 2008).

Santoso, Urip, Hukum Agraria Kajian Komperhensif (Kencana 2017).

Tutik, Titik Triwulan, Pengantar Hukum Perdata di Indonesia (Prestasi Pustaka Publisher 2006).

\section{Skripsi dan Tesis}

Hidayat, Rizki, ‘Tinjauan Hukum Terhadap Pelaksanaan Perjanjian Bagi Hasil Usaha Tambang Emas Antara Penambang dengan Pemilik Tanah (Studi Kasus di Kecamatan Natal Kabupaten Mandailing Natal)' (Skripsi, Fakultas Hukum Universitas Sumatera Utara 2017).

Pambudi Amira Inaz Clarissa, 'Prinsip Kepastian Hukm Kemitraan Petani Penggarap Dengan Perusahaan Perkebunan Atas Tanah Hak Guna Usaha' (Skripsi, Fakultas Hukum Universitas Jember 2019).

Panjaitan Mutiara, 'Faktor Penghambat Alokasi Luas Lahan Kebun Plasma Sebagai Syarat Perolehan Hak Guna Usaha Perkebunan Kelapa Sawit' (Tesis Fakultas Hukum, Universitas Sumatera Utara 2019).

Sinaga Rudianto Salmon, 'Masalah Hukum Dalam Perjanjian Kemitraan Inti Plasma Perkebunan Kelapa Sawit (Studi Kasus Pada PT.SHM dengan Koperasi PGH) dan Tindakan Notaris Dalam Menghadapi Perjanjian Kemitraan Inti Plasma Dalam Perkebunan Kelapa Sawit' (Tesis Fakultas Hukum, Universitas Indonesia 2011).

Suhitarasmi Dyah, 'Kewajiban Pemegang Hak Guna Usaha Dalam Pemanfaatan dan Penggunaan Tanah di Jawa Tengah' (Tesis Magister Kenotariatan, Universitas Diponegoro 2003).

\section{Jurnal dan Makalah}

Fadjar Undang, 'Kemitraan Usaha Perkebunan: Perubahan Struktur Yang Belum Lengkap' (2006) 24 Forum Penelitian Agro Ekonomi.

Purnami Tri, ‘Pelaksanaan Bagi Hasil Tanah Pertanian, (Studi Komparatif UndangUndang No.2 Tahun 1960 Tentang Perjanjian Bagi Hasil Tanah Pertanian Dengan Pelaksanaan Bagi Hasil Di Desa Blagungan Kecamatan Kalijambe Kabupaten Sragen)' (2012) Naskah Publikasi, Universitas Muhammadiyah 
Surakarta.

Sirait Janri Wolden Halomoan, 'Implementasi Kebijakan Pemberian Hak Guna Usaha' (2017) 14 Jurnal Ilmu Administrasi Negara.

Suharningsih, 'Kebijakan Pertanahan Pada Era Otonomi Daerah Di Bidang Hak Guna Usaha Perkebunan’ (2011) 23 Mimbar Hukum.

\section{Laman}

Fahamsyah, Ermanto, 'UU Perkebunan dan Urgensi Peraturan Pelaksanannya', $<$ https:/ / business-law.binus.ac.id/2014/12/14/uu-perkebunan-danurgensi-peraturan pelaksanaannya/ $>$.

Purnamasari Irma Devita, 'Akta Notaris Sebagai Akta Otentik', <https://www. hukumonline.com/klinik/detail/ulasan/lt550c0a7450a04/akta-notarissebagai-akta-otentik/>.

Mahdi Audi Yuliani, 'Analisis Yuridis Mengenai Sengketa Kedudukan Penyewa Tanah (Studi Terhadap Putusan Pengadilan Negeri Medan No. 562/ PDT.G/1995/PN-MDN), <https://jurnal.usu.ac.id/index.php/premise/ article/view/19373/8176>.

\section{Perundang-undangan}

Undang-Undang Dasar Negara Republik Indonesia tahun 1945.

Burgerlijk WetBoek.

Undang-Undang Nomor 5 tahun 1960 tentang Peraturan Dasar Pokok Pokok Agraria (Lembar Negara 1960-104).

Undang-Undang Republik Indonesia Nomor 2 Tahun 1960 tentang Perjanjian Bagi Hasil.

Undang-Undang Republik Indonesia Nomor 30 Tahun 2004 tentang Jabatan Notaris (Lembaran Negara Republik Indonesia Tahun 2004 Nomor 117).

Undang-Undang Republik Indonesia Nomor 39 Tahun 2014 tentang Perkebunan (Lembaran Negara Republik Indonesia Tahun 2014 Nomor 308).

Peraturan Pemerintah Republik Indonesia Nomor 40 Tahun 1996 tentang Hak Guna Usaha, Hak Guna Bangunan Dan Hak Pakai Atas Tanah (Lembaran Negara Republik Indonesia Tahun 1996 Nomor 58). 
Peraturan Menteri Pertanian Republik Indonesia Nomor 98/Permentan/ Ot.140/9/2013 tentang Pedoman Perizinan Usaha Perkebunan (Berita Negara Republik Indonesia Tahun 2013 Nomor 1180).

Peraturan Menteri Agraria Dan Tata Ruang/ Kepala Badan Pertanahan Nasional Nomor 7 Tahun 2017 tentang Pengaturan dan Tata Cara Penetapan Hak Guna Usaha (Berita Negara Republik Indonesia Tahun 2017 Nomor 965).

How to cite: Iqra Elma Nurtama, 'Perjanjian Pengusahaan Tanah Perkebunan Yang Dikuasai Badan Hukum Oleh Pihak Ketiga' (2020) Vol. 3 No. 1 Notaire. 
106 Iqra Elma: Perjanjian Pengusahaan Tanah...

--Halaman ini sengaja dikosongkan- 